\title{
Uusioersily
}

\section{Dogfish glucagon analogues counter hyperglycaemia and enhance both insulin secretion and action in diet-induced obese diabetic mice}

O'Harte, F., Ng, T., Lynch, AM., Conlon, J. M., \& Flatt, P. (2016). Dogfish glucagon analogues counter hyperglycaemia and enhance both insulin secretion and action in diet-induced obese diabetic mice. Diabetes Obesity and Metabolism, 18(10), 1013-1024. https://doi.org/10.1111/dom.12713

Link to publication record in Ulster University Research Portal

\section{Published in:}

Diabetes Obesity and Metabolism

Publication Status:

Published (in print/issue): 13/09/2016

DOI:

10.1111/dom. 12713

\section{Document Version}

Author Accepted version

\section{General rights}

Copyright for the publications made accessible via Ulster University's Research Portal is retained by the author(s) and / or other copyright owners and it is a condition of accessing these publications that users recognise and abide by the legal requirements associated with these rights.

\section{Take down policy}

The Research Portal is Ulster University's institutional repository that provides access to Ulster's research outputs. Every effort has been made to ensure that content in the Research Portal does not infringe any person's rights, or applicable UK laws. If you discover content in the Research Portal that you believe breaches copyright or violates any law, please contact pure-support@ulster.ac.uk. 


\title{
Dogfish glucagon analogues counter hyperglycaemia and enhance both insulin
}

\section{secretion and action in diet-induced obese diabetic mice.}

\author{
Authors: \\ O'Harte, Finbarr Paul M \\ University of Ulster, The Saad Centre for Pharmacy \& Diabetes \\ $\mathrm{Ng}$, Ming $\mathrm{T}$ \\ University of Ulster, The Saad Centre for Pharmacy \& Diabetes \\ Lynch, Aisling M \\ University of Ulster, The Saad Centre for Pharmacy \& Diabetes \\ Conlon, J Michael \\ University of Ulster, The Saad Centre for Pharmacy \& Diabetes \\ Flatt, Peter R \\ University of Ulster, The Saad Centre for Pharmacy \& Diabetes, School of Biomedical Sciences \\ *The Saad Centre for Pharmacy \& Diabetes, University of Ulster ,oharte@ulster.ac.uk
}

\begin{abstract}
Aims: We investigated the antidiabetic actions of three dogfish glucagon peptide analogues (known GLP-1 and glucagon receptor co-agonists) following chronic administration to dietinduced high fat fed (HFD) diabetic mice. Materials and methods: NIH Swiss mice were preconditioned to a HFD (45\% fat) for 100 days, or control mice were fed a normal diet (10\% fat). Normal diet control and HFD control mice received twice daily i.p. saline and HFD groups $(\mathrm{n}=8)$ received twice daily injections of or exendin-4(1-39), [S2a]dogfish glucagon, [S2a]dogfish glucagon exendin-4(31-39) or [S2a]dogfish glucagon-Lys ${ }^{30}-\gamma$-glutamyl-PAL (25 nmol/kg body weight) for 51 days. Results: Following dogfish glucagon analogue treatment, there was a rapid and sustained decrease in non-fasting blood glucose and associated insulinotropic effect (ANOVA, $\mathrm{p}<0.05-\mathrm{p}<0.001$ ) compared to saline-treated HFD controls. All peptide treatments significantly improved i.p. and oral glucose tolerance with concomitant increased insulin secretion compared to saline-treated HFD controls $(\mathrm{p}<0.05-\mathrm{p}<0.001)$. Following chronic treatment, no receptor desensitisation was observed but insulin sensitivity was enhanced for all peptide treated groups $(\mathrm{p}<0.01-\mathrm{p}<0.001)$ except [S2a]dogfish glucagon. Both exendin-4 and
\end{abstract}

This article has been accepted for publication and undergone full peer review but has not been through the copyediting, typesetting, pagination and proofreading process, which may lead to differences between this version and the Version of Record. Please cite this article as doi: $10.1111 /$ dom. 12713

This article is protected by copyright. All rights reserved. 
[S2a]dogfish glucagon exendin-4(31-39) significantly reduced plasma triglycerides concentrations compared to lean controls $(\mathrm{p}=0.0105$ and $\mathrm{p}=0.0048$, respectively). Pancreatic insulin content was not affected by peptide treatments but [S2a]dogfish glucagon and [S2a]dogfish glucagon exendin-4(31-39) decreased pancreatic glucagon by $28-34 \%(p=0.0221$ and $p=0.0075$, respectively). The percentage $\beta$-cell area within islets was increased by exendin- 4 and peptide analogue treatment groups compared with HFD controls and the $\alpha$-cell area decreased $(p<0.05-p<0.01)$. Conclusions: Overall, dogfish glucagon co-agonist analogues demonstrated several beneficial metabolic effects showing therapeutic potential for T2DM.

Keywords: Dogfish glucagon, peptide analogues, chronic study, diabetic mice, co-agonist, glucagon like peptide-1, therapy

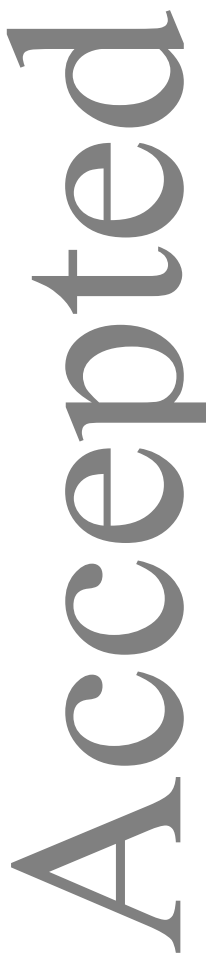

\section{Introduction:}

Glucagon is recognized for its role in preventing hypoglycaemia mainly through promoting hepatic glucose output in the fasting state [1], as well as having a pathogenic role in diabetes [2]. Thus hyperglycaemia makes an important contribution to elevated blood glucose concentrations in both Type 1 and Type 2 diabetes $[3,4]$. However, under different conditions, glucagon has several potentially beneficial extrahepatic actions including, stimulation of insulin secretion as well as promoting lipolysis, inhibiting feeding and enhancing energy expenditure [58].

Research on the use of stable incretin peptides (mimetics) for type 2 diabetes (T2DM) has expanded considerably over the past decade [9-11]. Exploitation of the multiple antidiabetic actions of GLP-1 have realized benefits including, enhancement of glucose-induced insulin This article is protected by copyright. All rights reserved. 
secretion, suppression of pancreatic glucagon secretion and appetite, slowing of postprandial gastric emptying, promotion of glucose uptake and possibly protection of pancreatic $\beta$-cell mass 10,12-14]. These benefits of GLP-1 have led to widespread clinical use of incretin mimetics such as exenatide (Byetta) and the GLP-1 receptor agonist liraglutide (Victoza) [15-20]. Coupled with this, there may be further therapeutic benefits from simultaneous activation of two or more receptor signaling pathways for the glucagon-secretin family of peptides, including glucagon, GIP as well as CCK-8 [21-23]. This has resulted in a growing interest in the use of dual or triple co-agonist peptides which could enhance multiple metabolic pathways and provide better and more physiological treatment options [14,21-29].

In particular, the simultaneous activation of the glucagon receptor (GCGR) and GLP-1 receptor (GLP-1R) exerts synergistically superior effects on body weight, glycaemic control and lipid metabolism [30-32]. A study by Pocai and colleagues [33] testing GLP-1/glucagon dualagonists found that normalisation of glycaemic control, as well as significant weight loss were more impressive in diet-induced obese mice treated with the dual agonist compared with a GLP1R selective agonist alone. In another study, GLP-1/glucagon co-agonism improved resting energy expenditure in obese mice, and it was inferred that the dual receptor activation would have beneficial effects also on glycaemic control and lipid metabolism in humans with T2DM [32].

We have a strong interest in examining the potential of peptide entities which have structural similarities with incretin hormones and glucagon in an attempt to uncover and test novel approaches to diabetes and obesity therapy [14,34-36]. In this regard, we were attracted to dogfish glucagon which exhibits strong structural similarities with human GLP-1, GIP and glucagon [37]. Comparison of the primary structures also indicates that dogfish glucagon shares three amino acid residues $\left(\mathrm{Glu}^{3}, \mathrm{Tyr}^{13}\right.$, and $\left.\mathrm{Lys}^{20}\right)$ with human GLP-1 that are not found in human glucagon (Table 1). This led us to hypothesise that dogfish glucagon may represent a template for the design of new antidiabetic peptides that may possess multiple agonist activity.

We have recently published a manuscript which examined the stability, in vitro insulinotropic action and in vivo acute biological activity including glucose lowering and insulin This article is protected by copyright. All rights reserved. 
secretory actions, as well as receptor specificity of 13 different analogues of dogfish glucagon [38]. From this initial work we wanted to evaluate the chronic metabolic effects of the most potent analogues. Thus in the present paper we report the ability of daily treatment with dogfish glucagon, a novel enzyme resistant (D-amino acid substitution at position 2) [S2a]dogfish glucagon and two sister analogues (modified to prolong their in vivo activities) to alleviate the symptoms associated with insulin resistance and Type 2 diabetes in mice resulting from chronic consumption of a high fat diet. We have compared the effects of 51 days treatment with these peptides with those of exendin-4 on glycaemic control, body weight, food intake, lipid metabolism, insulin sensitivity and pancreatic islet morphology in high fat fed DIO mice.

\section{Materials \& Methods:}

Synthetic Peptides. Table 1 displays the amino acid sequence of human glucagon, dogfish glucagon, GLP-1, GIP and three dogfish glucagon analogues used in this study. All peptides were purchased at $>95 \%$ purity from EZBiolabs (Carmel, IN, USA). In addition to QC data provided by the supplier, all peptides were checked for purity, characterized and structures confirmed using RP-HPLC and in-house matrix assisted laser desorption ionization-time of flight mass spectrometry (MALDI-ToF MS), as described previously [39].

The basic structure of dogfish glucagon was modified by substitution of D-Ala at the penultimate $\mathrm{N}$-terminal residue [S2a] to confer enzyme resistance. In addition, we extended the C-terminus of [s2a]dogfish glucagon with the last 9 C-terminal amino acid residues of exendin4(1-39) (P-S-S-G-A-P-P-P-S-amide), called [s2a]dogfish glucagon exendin-4(31-39) to help stabilize the molecule and improve its ability to interact with the GLP-1 receptor. Finally, a gamma-glutamyl spacer with palmitate adjunct was added at the Lys ${ }^{8}$ side-chain to [s2a]dogfish glucagon to promote albumin binding and extend its in vivo bioactivity as previously reported for stable incretin hormone analogues $[40,41]$.

\section{Animals.}

This article is protected by copyright. All rights reserved. 
Animal studies were carried out using male NIH Swiss TO mice supplied at 8-10 weeks of age by Harlan Ltd. (Blackthorne, UK). experimental diabetes was induced by feeding a high-fat diet for 100 days composed of $45 \%$ fat, $20 \%$ protein and $35 \%$ carbohydrate (total energy $26.15 \mathrm{KJ} / \mathrm{g}$; Special Diet Services, Essex, UK). Control mice were fed normal rodent chow (10\% fat, 30\% protein and $60 \%$ carbohydrate, total energy $12.99 \mathrm{KJ} / \mathrm{g}$, Trouw Nutrition, Cheshire, UK). The high fat fed group exhibited increased body weight and hyperglycaemia compared with normal diet controls (Fig. 1A, 1D). Animals were housed at $22 \pm 2{ }^{\circ} \mathrm{C}$ with a $12 \mathrm{~h}$ light: $12 \mathrm{~h}$ dark cycle (08:00-20:00 h), and had free access to drinking water and food. All animal experiments were conducted according to UK Animals (Scientific Procedures) Act 1986 and the "Principles of Laboratory Animal Care" (NIH Publication Number 86-23, revised 1985). No adverse effects were observed following administration of any of the peptides.

Chronic effect of twice daily i.p. administration of peptides on metabolic status in high fat fed mice

Normal mice and high fat diet fed mice $(n=8)$ received twice daily i.p. injections of saline vehicle $(0.9 \% \mathrm{NaCl}(\mathrm{w} / \mathrm{v}))$ at $08: 30$ and 17:30 for up to 65 days. Treatment groups of DIO mice $(\mathrm{n}=8)$ similarly received twice daily i.p. injections of [S2a]dogfish glucagon, [S2a]dogfish glucagon exendin-4(31-39), [S2a]dogfish glucagon-Lys ${ }^{30}-\gamma$-glutamyl-PAL or exendin-4(1-39) $(25 \mathrm{nmol} / \mathrm{kg}$ body weight). This dose was based upon responses derived from an earlier acute study [38]. A series of metabolic tests were performed (days 51 to 65) and both blood and tissue samples were collected at termination of the study (day 65).

\section{Metabolic tests and monitoring}

Food intake, body weight, blood glucose and plasma insulin were monitored at intervals of 2-3 days. Blood samples for glucose and plasma insulin were collected from the cut tail vein of conscious mice. Blood glucose was measured using an Acensia Contour meter (Bayer Healthcare, UK). Samples for insulin analysis were collected into chilled fluoride coated microcentrifuge This article is protected by copyright. All rights reserved. 
tubes (Sarstedt, Numbrecht, Germany). Blood was centrifuged at $4^{\circ} \mathrm{C}$ using a Beckman centrifuge for $3 \mathrm{~min}$ at $12,000 \times \mathrm{g}$ and resulting plasma aliquoted into Eppendorf tubes and stored at $-20^{\circ} \mathrm{C}$ prior to determination of insulin by modified dextran coated charcoal radioimmunoassay [42].

\section{Glucose tolerance, insulin sensitivity and peptide desensitisation tests}

Animals were fasted $18 \mathrm{~h}$ prior to administration of intraperitoneal or oral glucose alone (18 $\mathrm{mmol} / \mathrm{kg}$ body weight) or combined with either a dogfish glucagon analogue or exendin-4 (all at $25 \mathrm{nmol} / \mathrm{kg}$ body weight). Blood samples were collected prior to $(\mathrm{t}=0)$ and at $15,30,60,90$ and $120 \mathrm{~min}$ post injection. For assessment of insulin sensitivity, blood glucose was measured immediately prior to $(\mathrm{t}=0)$ and at 15,30 and 60 min following intraperitoneal administration of insulin (25 U/kg body weight). Results obtained provide an estimate of insulin action. Unfortunately, we were not able to conduct hyperinsulinaemic euglycaemic clamps in these mice. However, mice were assessed for desensitisation to peptide analogues following 51 days chronic administration. Glucose (18 mmol/kg body weight, i.p.) was administered alone or in combination with the peptide analogues (each at $25 \mathrm{nmol} / \mathrm{kg}$ body weight) to $18 \mathrm{~h}$ fasted mice. Blood samples were collected immediately prior to $(\mathrm{t}=0)$ and at 15,30 and 60 min post injection. Blood glucose was assessed immediately using a handheld Acensia Contour glucose meter (Bayer Healthcare, UK) and samples for insulin were collected and analysed as described above. Food and water were withheld throughout the study periods. All tests were conducted between day 51 and day 65 with twice daily injection regimens maintained throughout.

\section{Measurement of energy expenditure}

After 60 days, mice were placed in Complete Laboratory Animal Monitoring System (CLAMS) metabolic chambers (Columbus Instruments, Columbus, OH, USA) following injection of respective peptides at 12:00 h. Consumption of $\mathrm{O}_{2}$ and production of $\mathrm{CO}_{2}$ were measured for $30 \mathrm{~s}$ at $15 \mathrm{~min}$ intervals for a total period of $22 \mathrm{~h}$. Respiratory exchange ratio (RER) was calculated by dividing $\mathrm{VCO}_{2}$ by $\mathrm{VO}_{2}$. Energy expenditure was calculated using RER with the following equation $(3.815+1.232 \times \mathrm{RER}) \times \mathrm{VO}_{2}$ [43].

This article is protected by copyright. All rights reserved. 


\section{Tissue excision}

At the end of the study, non-fasted mice were killed by cervical dislocation. Blood was collected by cardiac puncture for determination of glucagon, amylase and lipids. The pancreas from each mouse were excised and taken for histology or wrapped in aluminium foil, snap frozen in liquid nitrogen with storage at $-70^{\circ} \mathrm{C}$ for subsequent determination of hormone contents.

\section{Assessment of plasma glucagon, amylase and lipid profile}

Glucagon was measured using an ELISA kit according to the manufacturer's instructions (Millipore, Billerica, Massachusetts, USA). Serum amylase was determined using an amylase colorimetric assay kit from Abcam (Cambridge, UK) according to the manufacturer's recommended protocol. Plasma lipid profile was determined using an I-Lab 650 clinical chemistry system (Instrumentation Laboratory, Warrington, UK), which included assessment of total cholesterol, triglycerides, and both HDL and LDL cholesterol. Reagents for triglycerides analysis were obtained from Instrumentation Laboratory (Warrington, UK) and reagents for LDL cholesterol were obtained from Randox (Crumlin, Co. Antrim, N. Ireland).

\section{Histological analyses and hormone contents of pancreatic tissue}

Pancreas tissues were fixed in $4 \%$ paraformaldehyde for $48 \mathrm{~h}$ at $4^{\circ} \mathrm{C}$ and then processed using automated tissue processor (Leica TP1020, Leica Microsystems, Nussloch, Germany). After embedding in paraffin wax, tissues were sectioned at $8 \mu \mathrm{m}$ thickness using a microtome (Shandon finesse 325 , Thermo scientific, UK) and sections were picked at an interval of 10 sections. The tissue sections were deparaffinised using Histoclear II (National Diagnostics, UK) and rehydrated through a series of ethanol. After antigen retrieval at $94^{\circ} \mathrm{C}$ for 20 min using citrate buffer $(\mathrm{pH}$ 6.0), the sections were blocked using $10 \%$ normal goat serum and incubated with primary antibodies overnight at $4^{\circ} \mathrm{C}$. The sections were then incubated with secondary antibodies for 45 min at $37^{\circ} \mathrm{C}$. The slides were mounted using anti-fade mounting medium and viewed under FITC filter (488 $\mathrm{nm}$ ) or TRITC filter (594 nm) using a fluorescent microscope (an Olympus system

This article is protected by copyright. All rights reserved. 
microscope, model BX51) and photographed using the DP70 camera adapter system [44,45]. All staining procedures and image analysis were carried out in a blinded manner. Approximately 150 islets were analysed per group. Islet parameters were determined using the 'closed polygon' tool in Olympus Cell $\wedge \mathrm{F}$ analysis software. Antibodies used were highly specific and showed no crossreactivity with related peptide hormones. For determination of pancreatic insulin and glucagon contents, pancreatic tissue was extracted in $5 \mathrm{ml} / \mathrm{g}$ acid ethanol (ethanol/0.7 M HCl; 3:1 ratio) as described previously [21].

\section{Statistical analysis}

Data was analysed using measures of one-way ANOVA followed by a Student Newman-Keuls post-hoc test or repeated measures of two tailed t-tests using GraphPad PRISM (Version 5.0 San Diego, CA, USA). Data are expressed as mean \pm SEM where $\mathrm{p}<0.05$ was considered to be statistically significant.

\section{Results:}

Effect of [S2a]dogfish glucagon, [S2a])dogfish glucagon exendin-4(31-39), [S2a]dogfish glucagon-Lys ${ }^{30}-\gamma$-glutamyl-PAL or exendin-4 on metabolic status

There was a rapid and sustained decrease in non-fasting blood glucose in all treatment groups ( $p<0.05-p<0.001)$, associated with elevated plasma insulin concentrations $(P<0.05-p<0.01$; Fig. 1A,B). Twice daily administration of the peptides had no significant effect on cumulative food intake or body weight (Fig.1C,D) or in the \% body weight change between experimental groups over 51 days (Fig. 1E). A small progressive increase in body weight was observed with saline treated high fat fed mice (Fig. 1D).

\section{Glucose tolerance}

Administration of [S2a]dogfish glucagon, [S2a]dogfish glucagon exendin-4(31-39), [S2a] dogfish glucagon-Lys ${ }^{30}-\gamma$-glutamyl-PAL or exendin-4 for 51 days significantly improved intraperitoneal and oral glucose tolerance compared to high-fat fed saline treated control mice $(\mathrm{p}<0.05$ $\mathrm{p}<0.001$ ) (Fig. 2A,B). Furthermore, there was a significant increase in plasma insulin This article is protected by copyright. All rights reserved. 
concentrations were noted over 120 min with all of the treated groups. Importantly, [S2a]dogfish glucagon exendin-4(31-39) was the most effective therapy at increasing the overall plasma insulin release post i.p. glucose load compared to high-fat fed saline treated controls $(p<0.05-p<0.001)$ (Fig. 2A). Similarly, an oral glucose challenge showed very similar responses to those observed following the ipGGT described above (Fig 2B).

\section{Effect of dogfish glucagon analogues on peptide desensitization and insulin sensitivity}

Chronic treatment of high-fat fed mice with exendin- 4 or dogfish glucagon analogues might lead to receptor desensitization and so we tested mice for this type of response. Mice which had been exposed to twice daily i.p. injections of these peptides for 51 days were tested. When given in combination with glucose, each of these peptides significantly suppressed the rise in blood glucose by $34.8 \%$ to $55.2 \%$ following i.p. glucose administration $(p<0.05-p<0.001)$ (Fig. $3 \mathrm{~A})$. In addition, each of the peptides elicited a significant insulin response (1.8- to 2.3-fold increase; $\mathrm{p}<0.05-\mathrm{p}<0.001$ ) (Fig. 3B), indicating absence of receptor desensitisation or receptor tachyphylaxis.

As shown in Fig. 3C, the glucose lowering effects of insulin were enhanced in all groups following chronic peptide administration (Fig. 3C). Overall insulin sensitivity as assessed by integrated area above the curve $\left(\mathrm{AAC}_{(0-120 \mathrm{~min})}\right)$ analysis was enhanced for all peptide treated groups (by $13.7 \%$ to $21.7 \%$ ) except for [S2a]dogfish glucagon, compared to saline treated high fat fed controls (Fig. 3C). Indeed, insulin sensitivity of peptide treated mice was similar to that of the lean mice fed the normal rodent diet (Fig. 3C).

Effect of dogfish glucagon analogues on circulating lipids, amylase and glucagon concentrations

The elevated levels of plasma total cholesterol in high fat fed mice $(\mathrm{p}<0.01)$ were not reversed by administration of [S2a]dogfish glucagon, [S2a]dogfish glucagon exendin-4(31-39), [S2a]dogfish glucagon-Lys ${ }^{30}-\gamma$-glutamyl-PAL or exendin-4 (Fig 4A). Peptide treatments did not alter the This article is protected by copyright. All rights reserved. 
HDL-cholesterol response in high fat fed mice, except for [S2a]dogfish glucagon exendin-4(3139) which reduced the HDL-cholesterol concentrations (Fig. 4B; $p=0.0315$ ). Similarly, the peptide treatments failed to counteract the rise in LDL-cholesterol found in high fat fed mice, except for the acylated [S2a]dogfish glucagon-Lys ${ }^{30}-\gamma$-glutamyl-PAL group which exhibited similar levels to lean mouse controls (Fig. 4C). Both exendin-4 and [S2a]dogfish glucagon exendin-4(31-39) significantly reduced plasma triglycerides concentrations compared to lean controls (Fig. 4D; $\mathrm{p}=0.0105$ and $\mathrm{p}<0.0048$, respectively).

As shown in Fig 5A, circulating amylase concentrations were similar in all groups of mice, indicating lack of adverse effect on pancreatic exocrine function and pancreatitis. Plasma glucagon was elevated by chronic high fat feeding (Fig. 5B; $\mathrm{p}<0.01$ ). This hyperglucagonaemia was significantly reduced by treatment with each of the three dogfish glucagon analogues

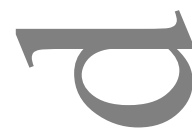
$(\mathrm{p}<0.05-\mathrm{p}<0.01)$ but not by exendin-4 (Fig. 5 C).

\section{Effect of dogfish glucagon analogues on pancreatic hormone content and islet morphology}

Saline treated DIO mice had an increased pancreatic insulin and glucagon content $(\mathrm{p}<0.05)$ compared with mice fed a normal diet (Fig. 5C,D). Insulin content was not affected by any of the peptide treatments (Fig. 5B) but [S2a]dogfish glucagon and [S2a]dogfish glucagon exendin-3(3139) decreased pancreatic glucagon by $28-34 \%((\mathrm{p}=0.0221$ and $\mathrm{p}=0.0075$, respectively, Fig. 5D).

Fig. 6A shows representative images of pancreatic islet morphology in high fat fed mice following chronic peptide treatments. [S2a]dogfish glucagon exendin-4(31-39) caused a small reduction in the number of pancreatic islets versus saline treated high fat fed controls (Fig. 6B). Smaller islets were also detected in [S2a]dogfish glucagon treated mice $($ Fig. 6C; $<<0.05)$ which might indicate decreased insulin demand due to improved insulin sensitivity. The percentage pancreatic $\beta$-cell area within islets was increased by $9.7 \%$ to $17.0 \%$ in all four peptide treated groups compared with high fat fed controls (Fig. 6D; $<<0.05-\mathrm{p}<0.01$ ) and conversely the peptide

This article is protected by copyright. All rights reserved. 
treatments led to a reduction in the $\% \alpha$-cell area by 25.9 to $45.5 \%$ within islets (Fig. $6 \mathrm{E} ; \mathrm{p}<0.05$ $\mathrm{p}<0.01)$

\section{Effect of dogfish glucagon analogues on energy expenditure}

There were no significant changes in oxygen consumption, carbon dioxide production, respiratory exchange or energy expenditure following treatment with dogfish glucagon analogues versus controls (Supplementary Figs. 1-4).

\section{Discussion:}

Dogfish glucagon has structural similarities to mammalian glucagon ( $83 \%$ sequence homology), GLP-1 (55\%) and GIP (53\%) and as such provides a possible template for development of potential multi-acting peptides. An earlier study in our laboratory has demonstrated that [S2a]dogfish glucagon and related analogues can activate both the GLP-1 and glucagon receptors without appreciable effects at the GIP receptor [38]. This is an important finding because coagonist peptides afford novel therapeutic agents which could be beneficial in combatting the growing global health challenge of T2DM, obesity and related metabolic diseases $[14,22,28,33,46]$.

In the current study, we examined the metabolic effects of twice daily dogfish glucagon analogue administration for 51 days in mice that had been pre-conditioned to develop obesity related diabetes by feeding a high fat diet [47]. Dogfish glucagon like its mammalian counterpart is susceptible to rapid degradation by DPP-4 removing the N-terminal dipeptide $\mathrm{His}^{1}-\mathrm{Ser}^{2}$ producing the truncated fragment glucagon(3-29). Thus we developed structurally modified stable analogues including [S2a]dogfish glucagon, [S2a]dogfish glucagon exendin-4(31-39), [S2a]dogfish glucagon-Lys ${ }^{30}-\gamma$-glutamyl-PAL [38] to compare with the established therapeutic GLP-1 mimetic exendin-4.

Over the course of the study, we observed a marked and sustained improvement in glycaemic control in all peptide treated groups compared to saline treated high fat fed controls. This article is protected by copyright. All rights reserved. 
Non fasting blood glucose concentrations were decreased and plasma insulin concentrations enhanced. However, no significant changes were noted in food intake despite a small reduction in body weight gain in the [S2a]dogfish glucagon, [S2a]dogfish glucagon exendin-4(31-39) and [S2a]dogfish glucagon-Lys ${ }^{30}-\gamma$-glutamyl-PAL treated groups. This might be related to small imbalance between energy intake and expenditure although we failed to demonstrate changes in the latter using CLAMS monitoring. Interestingly, other studies in rodents have also failed to show benefit of exendin-4 on body weight or food intake $[48,49]$.

In contrast, major metabolic benefits were observed in all groups of peptide treated high fat fed mice. The improvements in oral and intraperitoneal glucose tolerance, insulin secretion, lipid metabolism and insulin sensitivity evident with the [S2a]dogfish glucagon analogues correlate well with effects of exendin-4 and other studies which examined metabolic responses to oxyntomodulin or dual acting agonists in diet-induced obese mice [21.30,31,33]. In support of our findings, these researchers noted improvements in insulin sensitivity and lipid levels which were mostly independent of the food intake or a body weight lowering effects [31,33]. Our outcomes also correlate well with findings by Finan and colleagues [28] using another dual agonist approach activating both GLP-1 and GIP receptors. These results along with good acute glucose-lowering and insulin-releasing responses to [S2a]dogfish glucagon peptides in mice receiving chronic peptide treatments indicate no loss of bioactivity or receptor tachyphylaxis. Furthermore, none of the treatments had adverse effects over 65 days on circulating amylase concentrations thereby revealing no indication of possible pancreatitis as reported for GLP-1 mimetics in some other studies [50-51]. Indeed, exendin-4 and [S2a]dogfish glucagon exendin4(31-39) had the additional benefit of decreasing circulating triglycerides.

Mice fed the high fat diet exhibited characteristic increases in plasma insulin and glucagon together with enhanced pancreatic hormone stores. Beta cell area was enhanced whereas islet number was unchanged as observed previously [52]. Chronic peptide treatment increased plasma insulin without affecting beta cell areas but islet alpha cell areas were decreased resulting in significant suppression of islet area with [S2a]dogfish glucagon. Plasma glucagon This article is protected by copyright. All rights reserved. 
concentrations were also suppressed suggesting that improvements in blood glucose control were due to combined benefits of improved insulin secretion, alpha cell function and insulin sensitivity. Overall, the effects of the different dogfish glucagon analogues were broadly similar, and longer-term studies might be necessary to reveal benefit of acylation which might be expected to impart greater benefit due to more sustained exposure due to albumin binding [53]. Further studies are required to explore this aspect including pharmacokinetic studies which are currently impossible to undertake due to the need for specific antibodies and assay development.

From these various metabolic observations, it is clear that dogfish glucagon does not operate in mice in a manner analogous to mammalian glucagon which increases plasma glucose concentrations. Indeed, this study and our previous in vitro and acute in vivo studies [38] suggest an action profile more similar to oxyntomodulin which is a naturally occurring C-terminally extended form of glucagon known to activate both glucagon and GLP-1 receptors $[22,43]$. Interestingly there is a significant difference in the C-terminal structure of these analogues compared with oxyntomodulin itself. Earlier work in our laboratory using receptor transfected cells and with specific antagonists indeed confirms that dogfish glucagon analogues activated both the glucagon and GLP-1 receptors but not the GIP receptor [38]. Furthermore, the peptides exhibited antihyperglycaemic and insulinotropic effects in GIP receptor knock-out (GIPR KO) mice, whereas these actions were significantly curtailed in mice without functional GLP-1 receptors [38].

Significant evidence has been obtained recently from preclinical studies to support a positive role for glucagon acting as a satiety factor, increasing resting energy expenditure and promoting lipolysis in adipose tissue [1,4,54]. As highlighted in recent years, GLP-1 has many physiological actions which can help ameliorate diabetes, including reduction of food intake, slowing of gastric emptying, promotion of glucose uptake in peripheral tissues, inhibition of glucagon release and stimulation of glucose-dependent insulin secretion and enhancement of beta cell function $[13,14]$. The results of the present study demonstrated that stable dogfish glucagon

This article is protected by copyright. All rights reserved. 
analogues can counteract the diabetogenic influence of high fat feeding in mice. The analogues are at least as effective as exendin-4 (Byetta) and may provide a possible new unimolecular candidate molecule for T2DM treatment by co-agonistic action.

\section{Acknowledgements}

These studies were supported by POC grant from Invest Northern Ireland (POC308) and a research studentship from Northern Ireland Department of Education and Learning to AL.

\section{Conflict of Interest}

Ulster University and $\mathrm{FOH}, \mathrm{PRF}$ and JMC hold patents for use of therapeutic peptides for treatment of obesity-diabetes.

\section{Contributions}

FOH and PRF devised and planned the studies and wrote the manuscript. NG and AL carried out experimental work, analysed the data and commented on the manuscript. JMC contributed to analysis of data and revision of manuscript. All authors approved the final version of the manuscript.

This article is protected by copyright. All rights reserved. 


\section{References}

1. Davidson JA, Holland WL, Roth MG, et al. Glucagon therapeutics, dawn of a new era for diabetes care. Diabetes Metabolism Research and Reviews 2016 Jan 4. doi: 10.1002/dmrr.2773. [Epub ahead of print] Review.

2. Unger RH, Cherrington AD. Glucagonocentric restructuring of diabetes: a pathophysiologic and therapeutic makeover. Journal of Clinical Investigation 2012; 122: 4-12.

3. Farhy LS, McCall AL. Optimizing reduction in basal hyperglucagonaemia to repair defective glucagon counterregulation in insulin deficiency. Diabetes, Obesity and Metabolism 2011; 13: 133-143. Review

4. Campbell JE, Drucker DJ. Islet $\alpha$ cells and glucagon-critical regulators of energy homeostasis._Nature Reviews in Endocrinology 2015; 11: 329-338.

5. Gelling RW, Du XQ, Dichmann DS, et al. Lower blood glucose, hyperglucagonemia, and pancreatic $\alpha$ cell hyperplasia in glucagon receptor knockout mice. Proceedings of the National Academy of Sciences USA 2003; 100: 1438-1443.

6. Sadry SA, Drucker DJ. Emerging combinatorial hormone therapies for the treatment of obesity and T2DM. Nature Reviews Endocrinology 2013; 9: 425-433.

7. Charron MJ, Vuguin PM. Lack of glucagon receptor signaling and its implications beyond glucose homeostasis. Journal of Endocrinology 2015; 224: R123-R130.

This article is protected by copyright. All rights reserved. 
8. Ye L, Robertson MA, Hesselson D, Stainier DY, Anderson RM. Glucagon is essential for alpha cell transdifferentiation and beta cell neogenesis. Development 2015; 142: 1407-1417.

9. Holst JJ. Treatment of type 2 diabetes mellitus with agonists of the GLP-1 receptor or DPPIV inhibitors. Expert Opinion on Emerging Drugs. 2004; 9: 155-166. Review.

10. Campbell JE, Drucker DJ. Pharmacology, physiology, and mechanisms of incretin hormone action. Cell Metabolism 2013; 17: 819-837. Review.

11. Nauck M. Incretin therapies - highlighting common features and differences in the modes of action of GLP-1 receptor agonists and DPP-4 inhibitors. Diabetes, Obesity and Metabolism 2016; 18: 203-216.

12. Green BD, Gault VA, Mooney MH, et al. Degradation, receptor binding, insulin secreting and antihyperglycaemic actions of palmitate-derivatised native and $\mathrm{Ala}^{8}$-substituted GLP-1 analogues. Biological Chemistry 2004a; 385: 169-177.

13. Drucker DJ. Incretin action in the pancreas: potential promise, possible perils, and pathological pitfalls. Diabetes 2013; 62: 3316-3323. Review.

14. Irwin N, Flatt PR. New perspectives on exploitation of incretin peptides for the treatment of diabetes and related disorders. World Journal of Diabetes 2015; 6: 1285-1295.

15. Madsbad S. Exenatide and liraglutide: different approaches to develop GLP-1 receptor agonists (incretin mimetics)-preclinical and clinical results. Best Practice \& Research Clinical Endocrinology \& Metabolism 2009; 23: 463-477.

16. Nikfar S, Abdollahi M, Salari P. The efficacy and tolerability of exenatide in comparison to placebo; a systematic review and meta-analysis of randomized clinical trials. Journal of Pharmacology Pharmaceutical Science 2012; 15: 1-30. Review.

This article is protected by copyright. All rights reserved. 
17. Kela R, Davies MJ. Treatment evaluation of liraglutide in type 2 diabetes. Expert Opinion on Biological Therapy 2012; 12: 1551-1556. Review.

18. Wysham C, Grimm M, Chen S. Once weekly exenatide: efficacy, tolerability and place in therapy. Diabetes, Obesity and Metabolism 2013; 15: 871-881.

19. McCormack PL. Exenatide twice daily: a review of its use in the management of patients with type 2 diabetes mellitus. Drugs 2014; 74: 325-351. Review.

20. Scott LJ. Liraglutide: a review of its use in adult patients with type 2 diabetes mellitus. Drugs 2014; 74: 2161-2174. Review.

21. Irwin N, Pathak V, Flatt PR. A novel CCK-8/GLP-1 hybrid peptide exhibiting prominent insulinotropic, glucose-lowering, and satiety actions with significant therapeutic potential in high-fat-fed mice. Diabetes 2015; 64: 2996-3009.

22. Bhat VK, Kerr BD, Flatt PR, Gault VA. A novel GIP-oxyntomodulin hybrid peptide acting through GIP, glucagon and GLP-1 receptors exhibits weight reducing and anti-diabetic properties. Biochemical Pharmacology 2013a; 85: 1655-1662

23. Bhat VK, Kerr BD, Vasu S, Flatt PR, Gault VA. A DPP-IV-resistant triple-acting agonist of GIP, GLP-1 and glucagon receptors with potent glucose-lowering and insulinotropic actions in high-fat-fed mice. Diabetologia 2103b; 56: 1417-1424.

24. Tom I, Lee V, Dumas M, et al. Reproducible production of a PEGylated dual-acting peptide for diabetes. AAPS Journal 2007; 9: E227-E234.

This article is protected by copyright. All rights reserved. 
25. Franklin ZJ, McDonnell B, Montgomery IA, Flatt PR, Irwin N. Dual modulation of GIP and glucagon action by the low molecular weight compound 4-hydroxybenzoic acid 2bromobenzylidene hydrazide. Diabetes, Obesity and Metabolism 2011; 13: 742-749.

26. Fosgerau K, Jessen L, Lind Tolborg J, et al. The novel GLP-1-gastrin dual agonist, ZP3022, increases $\beta$-cell mass and prevents diabetes in $\mathrm{db} / \mathrm{db}$ mice. Diabetes, Obesity and Metabolism 2013; 15: 62-71.

27. Trevaskis JL, Mack CM, Sun C, et al. Improved glucose control and reduced body weight in rodents with dual mechanism of action peptide hybrids. PLoS one 2013; 8: e78154.

28. Finan B, Ma T, Ottaway N, et al. Unimolecular dual incretins maximize metabolic benefits in rodents, monkeys, and humans. Science Translational Medicine 2013; 5: 209 ra151.

29. Skarbaliene J, Secher T, Jelsing J, et al. The anti-diabetic effects of GLP-1-gastrin dual agonist ZP3022 in ZDF rats. Peptides 2015; 69: 47-55.

30. Kerr BD, Flatt PR, Gault VA. (D-Ser2)Oxm[mPEG-PAL]: a novel chemically modified analogue of oxyntomodulin with antihyperglycaemic, insulinotropic and anorexigenic actions. Biochemical Pharmacology 2010; 80: 1727-1735.

31. Patel V, Joharapurkar A, Dhanesha N, et al. Co-agonist of glucagon and GLP-1 reduces cholesterol and improves insulin sensitivity independent of its effect on appetite and body weight in diet-induced obese C57 mice. Canadian Journal of Physiology and Pharmacology 2013; 91: 1009-1015.

This article is protected by copyright. All rights reserved. 
32. Tan TM, Field BC, McCullough KA, et al. Coadministration of glucagon-like peptide-1 during glucagon infusion in humans results in increased energy expenditure and amelioration of hyperglycemia. Diabetes 2013; 62: 1131-1138.

33. Pocai A, Carrington PE, Adams JR, et al. Glucagon-like peptide 1/glucagon receptor dual agonism reverses obesity in mice. Diabetes 2009; 58: 2258-2266.

34. Irwin $\mathrm{N}$, Green $\mathrm{BD}$, Mooney $\mathrm{MH}$, et al. A novel, long-acting agonist of glucose-dependent insulinotropic polypeptide suitable for once-daily administration in type 2 diabetes. Journal of Pharmacology and Experimental Therapeutics 2005; 314: 1187-1194.

35. Gault VA, Kerr BD, Harriott P, Flatt PR. Administration of an acylated GLP-1 and GIP preparation provides added beneficial glucose-lowering and insulinotropic actions over single incretins in mice with Type 2 diabetes and obesity. Clinical Science (London). 2011b; 121: 107-117.

36. Gault VA, Bhat VK, Irwin N, Flatt PR. A novel glucagon-like peptide-1 (GLP-1)/glucagon hybrid peptide with triple-acting agonist activity at glucose-dependent insulinotropic polypeptide, GLP-1, and glucagon receptors and therapeutic potential in high fat-fed mice. Journal of Biological Chemistry 2013; 288: 35581-25591

37. Conlon JM, O'Toole L, Thim L. Primary structure of glucagon from the gut of the common dogfish, Scyliorhinus canicula. FEBS Letters 1987; 214: 50-56.

38. O'Harte FPM, Ng MT, Lynch AM, Conlon JM, Flatt PR. Novel dual agonist peptide analogues derived from dogfish glucagon show promising in vitro insulin releasing actions and antihyperglycaemic activity in mice. Mol Cell Endocrinol. 2016; 431: 133-144.

This article is protected by copyright. All rights reserved. 
39. Gault VA, Porter DW, Irwin N, Flatt PR. Comparison of sub-chronic metabolic effects of stable forms of naturally occurring GIP(1-30) and GIP(1-42) in high-fat fed mice. Journal of Endocrinology 2011a; 208: 265-271.

40. Holz GG, Chepurny OG. Glucagon-like peptide-1 synthetic analogs: new therapeutic agents for use in the treatment of diabetes mellitus. Current Medicinal Chemistry 2003; 10: 24712483. Review.

41. Knudsen LB. Glucagon-like peptide-1: the basis of a new class of treatment for type 2 diabetes. Journal of Medicinal Chemistry 2004; 47: 4128-4134.

42. Flatt PR, Bailey CJ. Development of glucose intolerance and impaired plasma insulin response to glucose in obese hyperglycaemic (ob/ob) mice. Hormone and Metabolic Research 1981; 13: 556-560.

43. Lynch AM, Pathak N, Flatt YE, et al. Comparison of stability, cellular, glucose-lowering and appetite supressing effects of oxyntomodulin analogues modified at the N-terminus. European Journal of Pharmacology 2014; 743: 69-78.

44. Vasu S, Moffett RC, Thorens B, Flatt PR. Role of endogenous GLP-1 and GIP in beta cell compensatory responses to insulin resistance and cellular stress. PLoS One. 2014; 9: e101005.

45. Moffett RC, Irwin N, Francis JM, Flatt PR. Alterations of glucose-dependent insulinotropic polypeptide and expression of genes involved in mammary gland and adipose tissue lipid metabolism during pregnancy and lactation. PLoS One 2013; 8: e78560.

This article is protected by copyright. All rights reserved. 
46. Day JW, Ottaway N, Patterson, JT, et al. (2009) A new glucagon and GLP-1 co-agonist eliminates obesity in rodents. Nature Chemical Biology 2009; 5: 749-757.

47. Buettner R, Schölmerich J, Bollheimer LC. High-fat diets: modeling the metabolic disorders of human obesity in rodents. Obesity (Silver Spring). 2007; 15: 798-808.

48. Irwin N, McClean PL, Cassidy RS, et al. Comparison of the anti-diabetic effects of GIP- and GLP-1-receptor activation in obese diabetic (ob/ob) mice: studies with DPP IV resistant NAcGIP and exendin(1-39)amide. Diabetes Metabolism Research Reviews 2007; 23: 572579.

49. Irwin N, Hunter K, Frizzell N, Flatt PR. Antidiabetic effects of sub-chronic activation of the GIP receptor alone and in combination with background exendin-4 therapy in high fat fed mice. Regulatory Peptides 2009; 153: 70-76.

50. Gier B, Matveyenko AV, Kirakossian D, Dawson D, Dry SM, Butler PC. Chronic GLP-1 receptor activation by exendin-4 induces expansion of pancreatic duct glands in rats and accelerates formation of dysplastic lesions and chronic pancreatitis in the $\operatorname{Kras}(\mathrm{G} 12 \mathrm{D})$ mouse model. Diabetes 2012; 61: 1250-1262.

51. Rouse R, Xu L, Stewart S, Zhang J. High fat diet and GLP-1 drugs induce pancreatic injury in mice. Toxicology and Applied Pharmacology 2014; 276: 104-114.

52. Moffett RC, Vasu S, Flatt PR. Functional GIP receptors play a major role in islet compensatory response to high fat feeding in mice. Biochimica et Biophysica ACTA (General Subjects) 2015; 1850: 1206-1214.

This article is protected by copyright. All rights reserved. 
53. Lee J, Lee C, Kim I, et al. Preparation and evaluation of palmitic acid-conjugated exendin-4 with delayed absorption and prolonged circulation for longer hypoglycemia. International Journal of Pharmacology 2012; 424: 50-57.

54. Habegger KM, Heppner KM, Geary N, Bartness TJ, DiMarchi R, Tschöp $\quad M H$. The metabolic actions of glucagon revisited. Nature Reviews Endocrinology 2010; 6: 689-697.
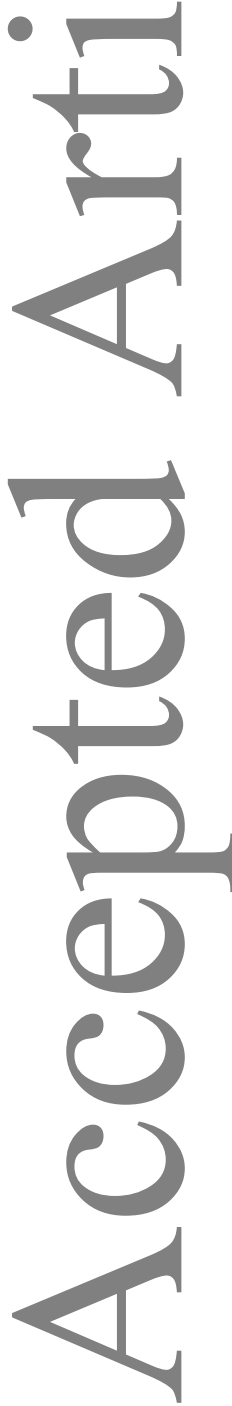

This article is protected by copyright. All rights reserved. 


\section{Legends to Figures:}

Fig. 1 Chronic effect of twice daily administration of exendin-4, [S2a]dogfish glucagon, [S2a]dogfish glucagon-exendin-4(31-39) and [S2a]dogfish glucagon-Lys ${ }^{30}-\gamma$-glutamyl-PAL (each at $25 \mathrm{nmol} / \mathrm{kg}$ body weight) on non-fasting (A) blood glucose, (B) plasma insulin, (C) cumulative food intake, (D) body weight and (E) \% body weight change in high-fat fed mice during 51 day treatment. The black horizontal bar represents the treatment period. Values represent mean \pm SEM for 8 mice. ${ }^{*} \mathrm{p}<0.05,{ }^{* *} \mathrm{p}<0.01$ and ${ }^{* * *} \mathrm{p}<0.001$ compared to saline treated control.

Fig. 2 Effect of twice daily administration of exendin-4, [S2a]dogfish glucagon, [S2a]dogfish glucagon-exendin-4(31-39) and [S2a]dogfish glucagon-Lys ${ }^{30}-\gamma$-glutamyl-PAL on blood glucose and plasma insulin in response to an intraperitoneal $(A, C)$ and oral $(B, D)$ glucose challenge in high-fat diet fed mice. Tests were performed following 51 days of twice daily intraperitoneal administration of saline $((0.9 \% \mathrm{w} / \mathrm{v}) \mathrm{NaCl})$, exendin- 4 or dogfish glucagon analogues (each at 25 $\mathrm{nmol} / \mathrm{kg}$ body weight). Mice were fasted for $10 \mathrm{~h}$ previously. Blood glucose (A and B) and plasma insulin concentrations $(C$ and $D)$ were measured prior to and after i.p. $(A, C)$ or oral $(B, D)$ administration of glucose $(18 \mathrm{mmol} / \mathrm{kg}$ body weight $)$. Blood glucose and integrated plasma insulin response (Area Under the Curve, AUC) are also included. Values represent mean \pm SEM for 8 mice. ${ }^{*} \mathrm{p}<0.05, * * \mathrm{p}<0.01$ and $* * * \mathrm{p}<0.001$ compared with saline-treated control.

Fig. 3 Effect of twice daily administration of exendin-4, [S2a]dogfish glucagon, [S2a]dogfish glucagon-exendin-4(31-39) and [S2a]dogfish glucagon-Lys ${ }^{30}-\gamma$-glutamyl-PAL on blood glucose (A) and plasma insulin (B) in response to peptide desensitisation and insulin sensitivity (C) in high-fat diet fed mice. Tests were performed following 51 days of twice daily intraperitoneal administration of saline $((0.9 \% \mathrm{w} / \mathrm{v}) \mathrm{NaCl})$, exendin- 4 or dogfish glucagon analogues (each at 25 $\mathrm{nmol} / \mathrm{kg}$ body weight). Blood glucose and plasma insulin concentrations were measured prior to and after i.p. administration of each peptide $(25 \mathrm{nmol} / \mathrm{kg}$ body weight $)$ with glucose $(18 \mathrm{mmol} / \mathrm{kg}$

This article is protected by copyright. All rights reserved. 
body weight) in $10 \mathrm{~h}$ fasted mice. For insulin sensitivity, insulin ( $25 \mathrm{U} / \mathrm{kg}$ bw) was administrated by i.p. injection to fed mice at $\mathrm{t}=0 \mathrm{~min}$. Blood glucose and plasma insulin AUC values are also included. Values represent mean \pm SEM for 8 mice. ${ }^{*} \mathrm{p}<0.05, * * \mathrm{p}<0.01$ and $* * * \mathrm{p}<0.001$ compared with saline-treated control.

Fig. 4 Effects of twice daily administration of saline, exendin-4, [S2a]dogfish glucagon, [S2a]dogfish glucagon-exendin-4(31-39) and [S2a]dogfish glucagon-Lys ${ }^{30}-\gamma$-glutamyl-PAL PAL (each at $25 \mathrm{nmol} / \mathrm{kg}$ body weight) on (A) plasma total cholesterol, (B) HDL cholesterol, (C) plasma triglycerides and (D) LDL cholesterol and (D) following 65 day treatment of high-fat fed and lean control mice. Values are mean \pm SEM for $n=8$. ${ }^{*} \mathrm{p}<0.05$ and $* * \mathrm{p}<0.01$ compared with saline treated control. $+p<0.05$ and $++p<0.01$ compared with lean mice.

Fig. 5 Effects of twice-daily i.p. administration of saline, exendin-4, [S2a]dogfish glucagon, [S2a]dogfish glucagon-exendin-4(31-39) and [S2a]dogfish glucagon-Lys ${ }^{30}-\gamma$-glutamyl-PAL (each at $25 \mathrm{nmol} / \mathrm{kg}$ body weight) on (A) amylase activity, (B) plasma glucagon, (C) pancreatic insulin content and (D) pancreatic glucagon content. Observations were made following 65 day treatment of high fat fed and lean control mice. Values are mean \pm SEM for $n=8$. ${ }^{*} \mathrm{p}<0.05$ and ${ }^{* *} \mathrm{p}<0.01$ compared with saline treated control. $+\mathrm{p}<0.05$ and $++\mathrm{p}<0.01$ compared with lean mice.

Fig. 6 Effects of twice-daily i.p. administration of saline, exendin-4, [S2a]dogfish glucagon, [S2a]dogfish glucagon-exendin-4(31-39) and [S2a]dogfish glucagon-Lys ${ }^{30}-\gamma$-glutamyl-PAL (each at $25 \mathrm{nmol} / \mathrm{kg}$ body weight) following 65 day administration on (A) islet morphology, (B) number of islets, (C) islet area, (D) beta cell area and (E) alpha cell area. Observations were made following 65 day treatment of high fat fed and lean control mice. Representative images are shown in (A) all at $x 40$ magnification. Values are mean \pm SEM for $n=8$. ${ }^{*} \mathrm{p}<0.05$ and ${ }^{* *} \mathrm{p}<0.01$ compared with saline treated control. $+\mathrm{p}<0.05$ compared with exendin-4 treated group.

This article is protected by copyright. All rights reserved. 
Figure 1
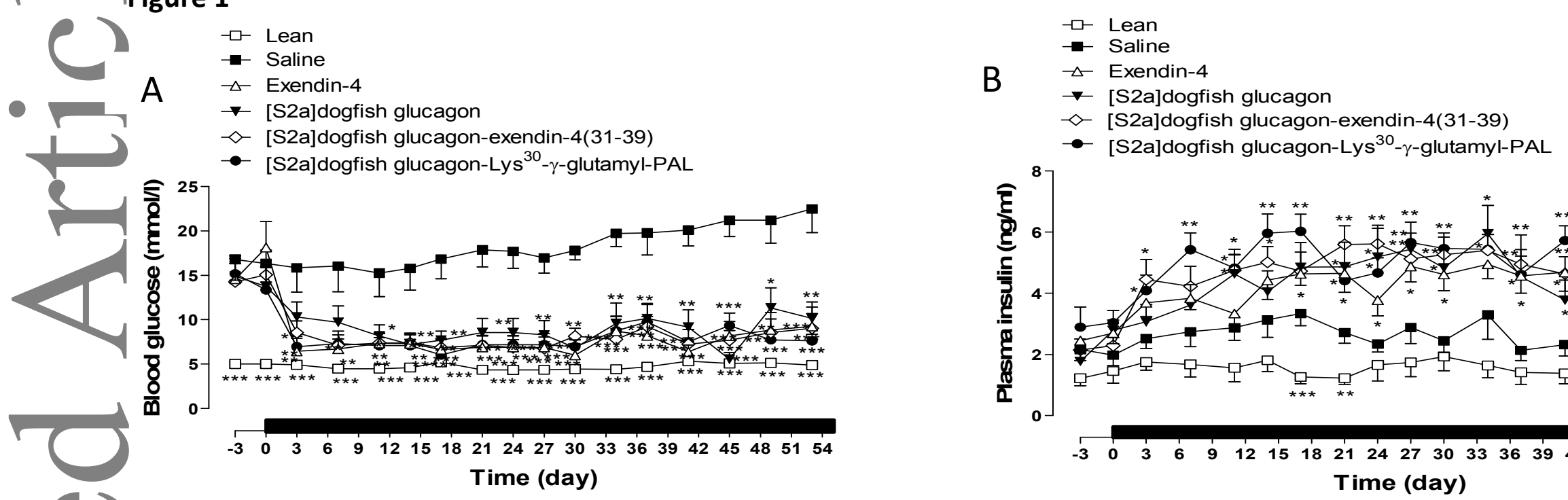

(1)

Time (day)

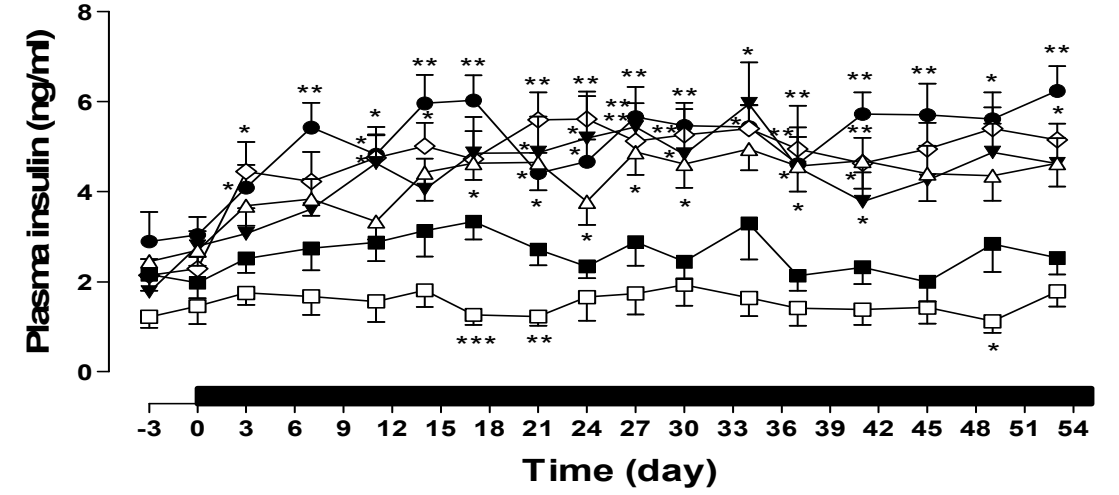

\section{- C $\quad$ b Lean}

$\square$ Exendin-4

[S2a]dogfish glucagon

[S2a]dogfish glucagon exendin-4(31-39)

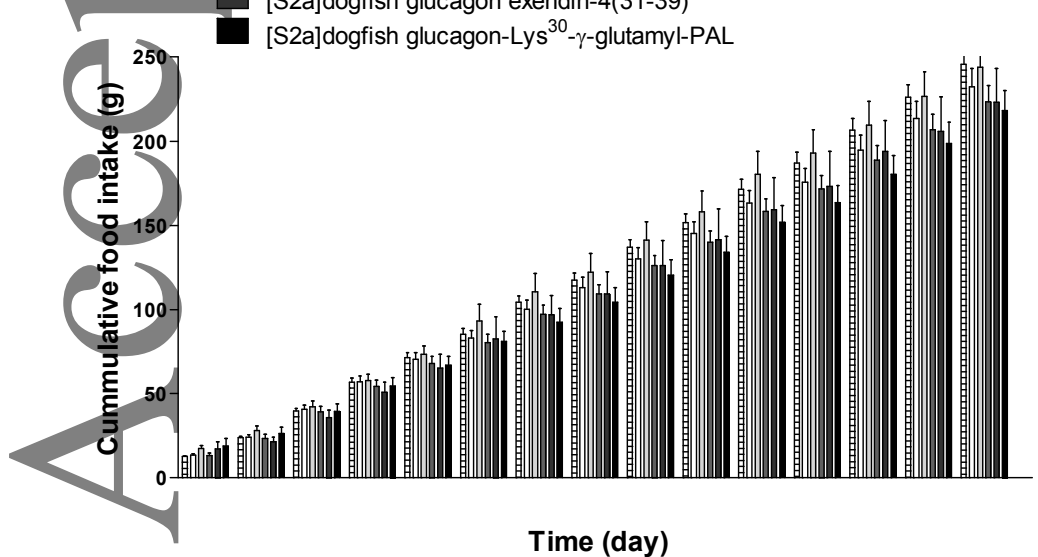

Time (day)
D $\quad-$ Lean

- Saline

$\checkmark$ Exendin-4

* [S2a]dogfish glucagon

$\diamond$ [S2a]dogfish glucagon-exendin-4(31-39)

- [S2a]dogfish glucagon-Lys ${ }^{30}-\gamma$-glutamyl-PAL

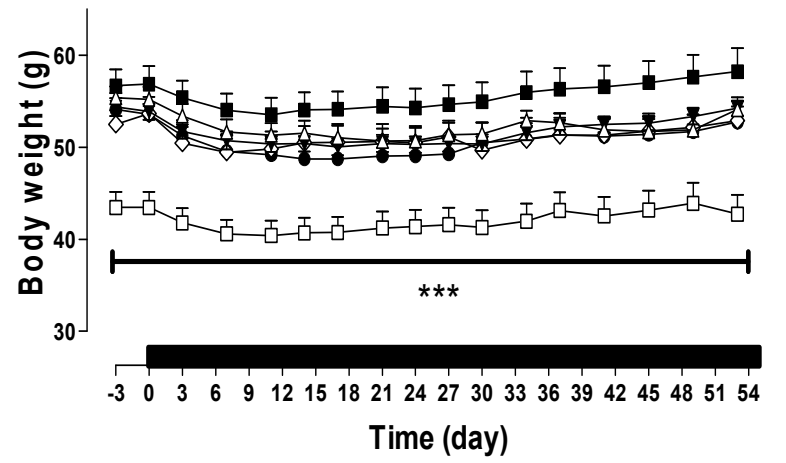

E m Lean

$\square$ Saline

$\square$ [S2a]dogfish glucagon

$\square$ [S2a]dogfish glucagon-exendin-4(31-39)

[S2a]dogfish glucagon-Lys ${ }^{30}-\gamma$-glutamyl-PAL

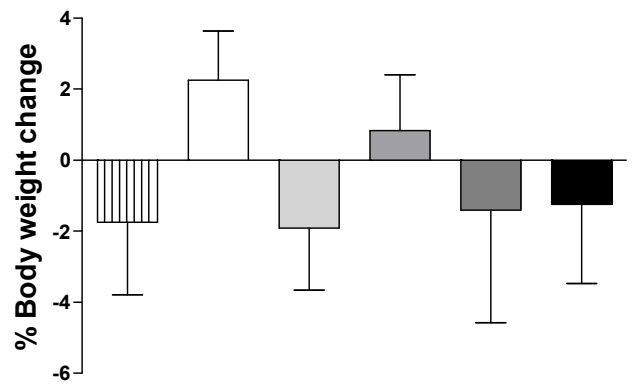

This article is protected by copyright. All rights reserved. 


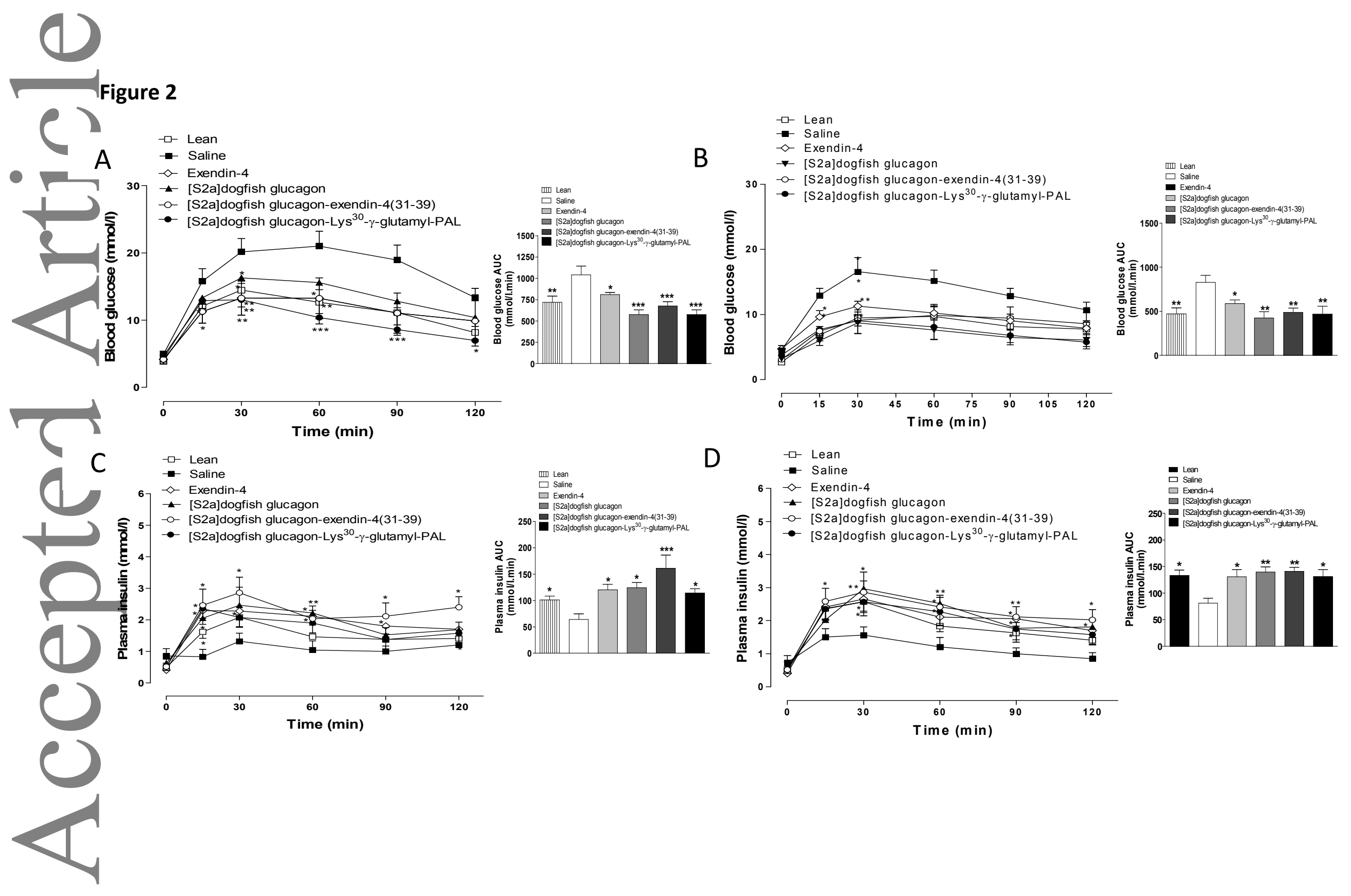

This article is protected by copyright. All rights reserved. 


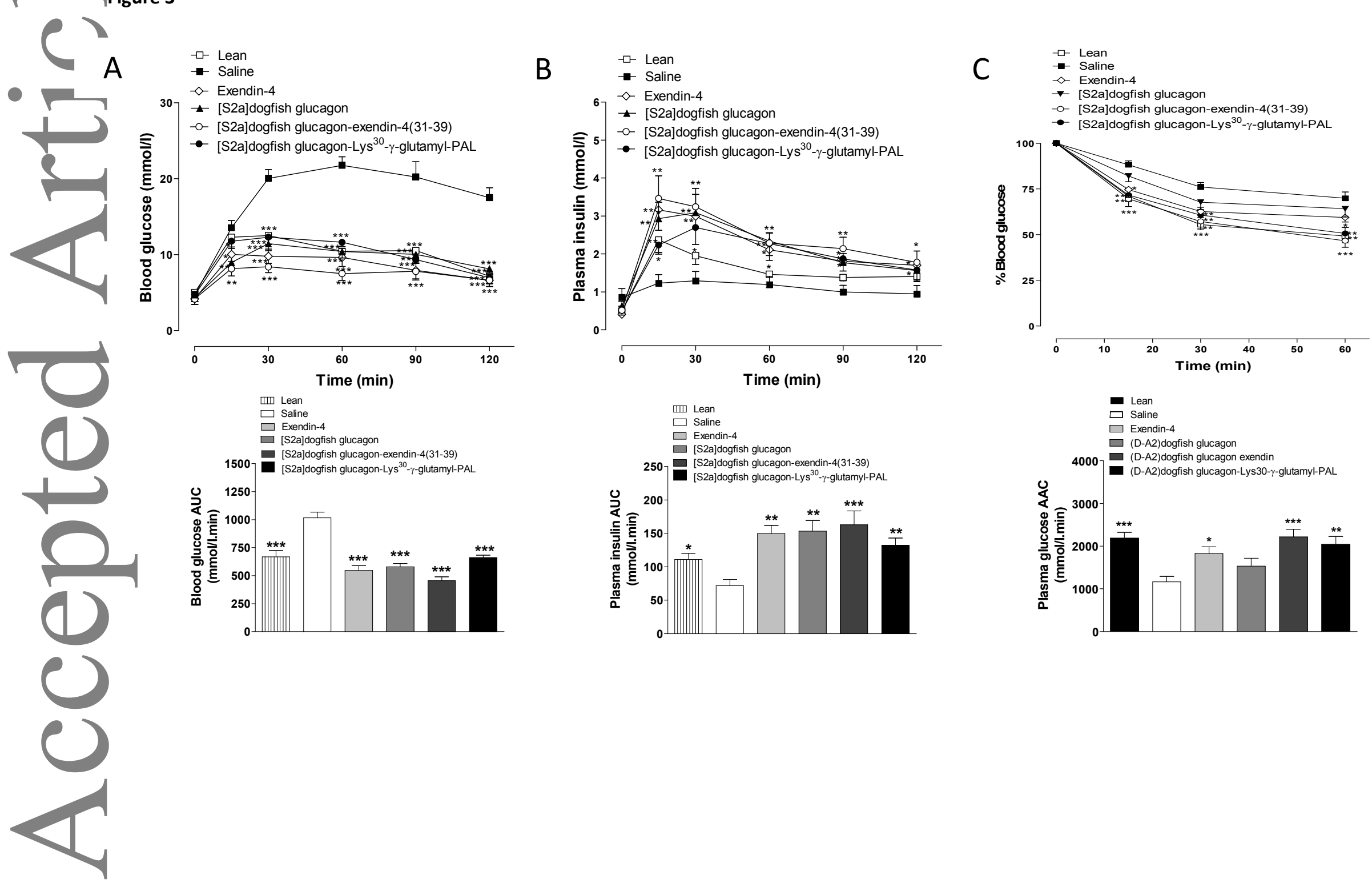

This article is protected by copyright. All rights reserved. 
Figure 4

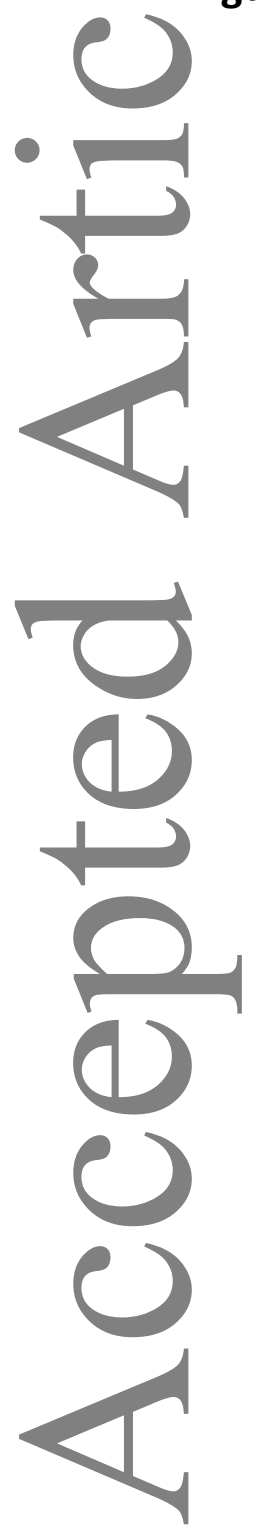

B

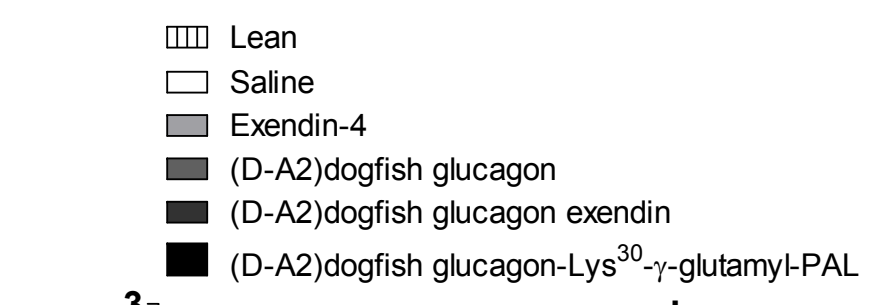

C
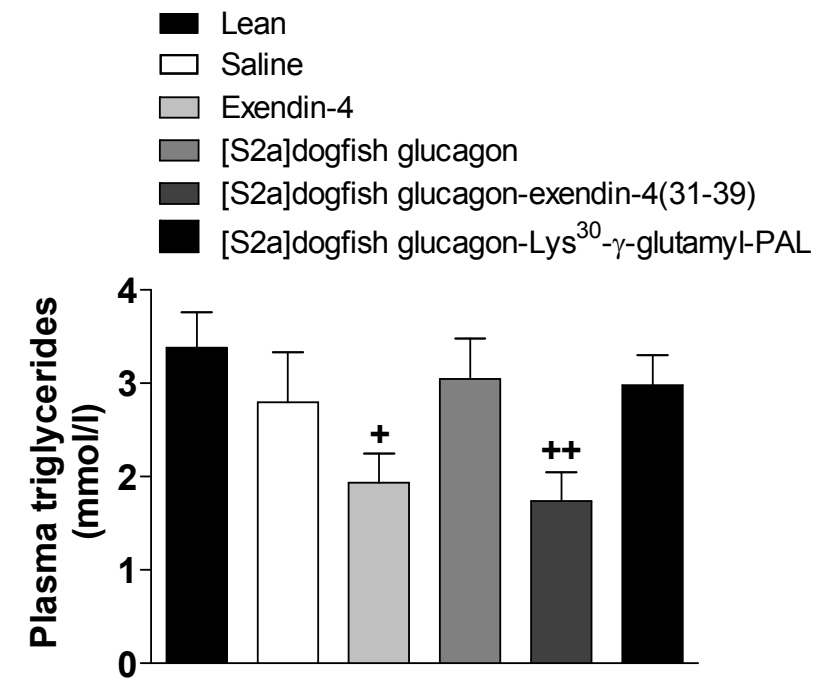

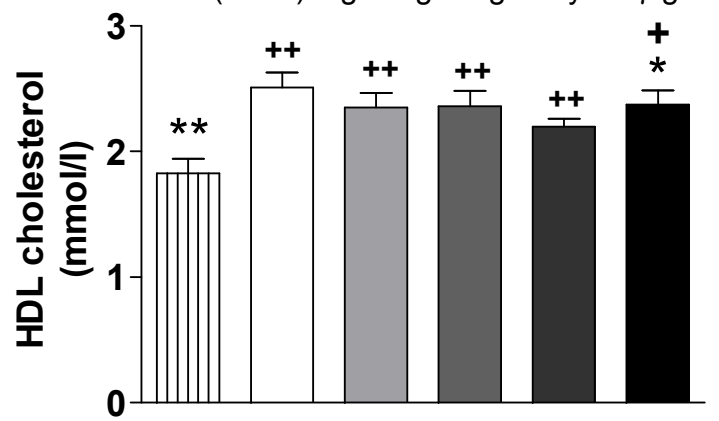

D

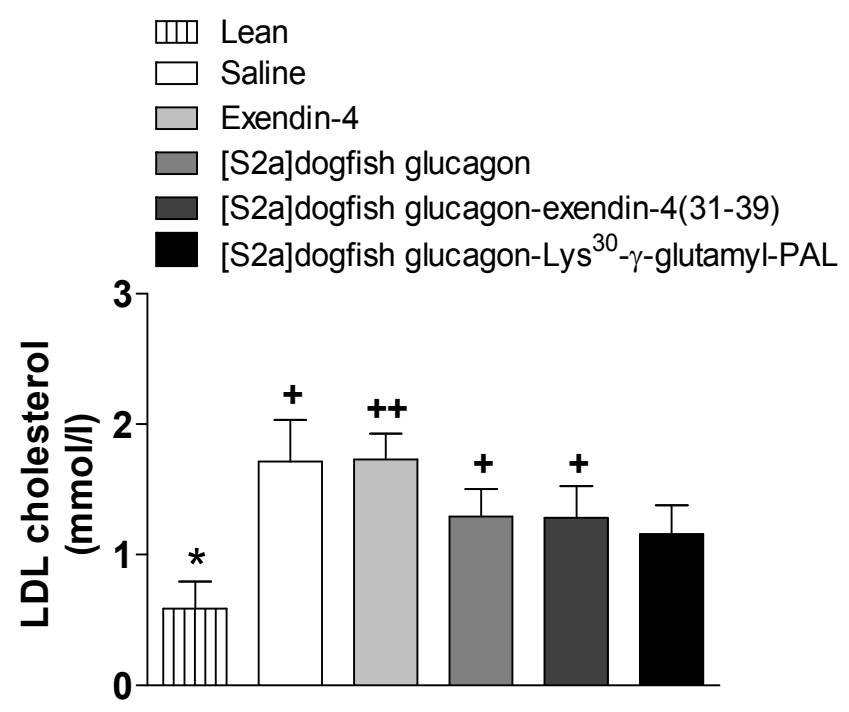

This article is protected by copyright. All rights reserved. 
Figure 5

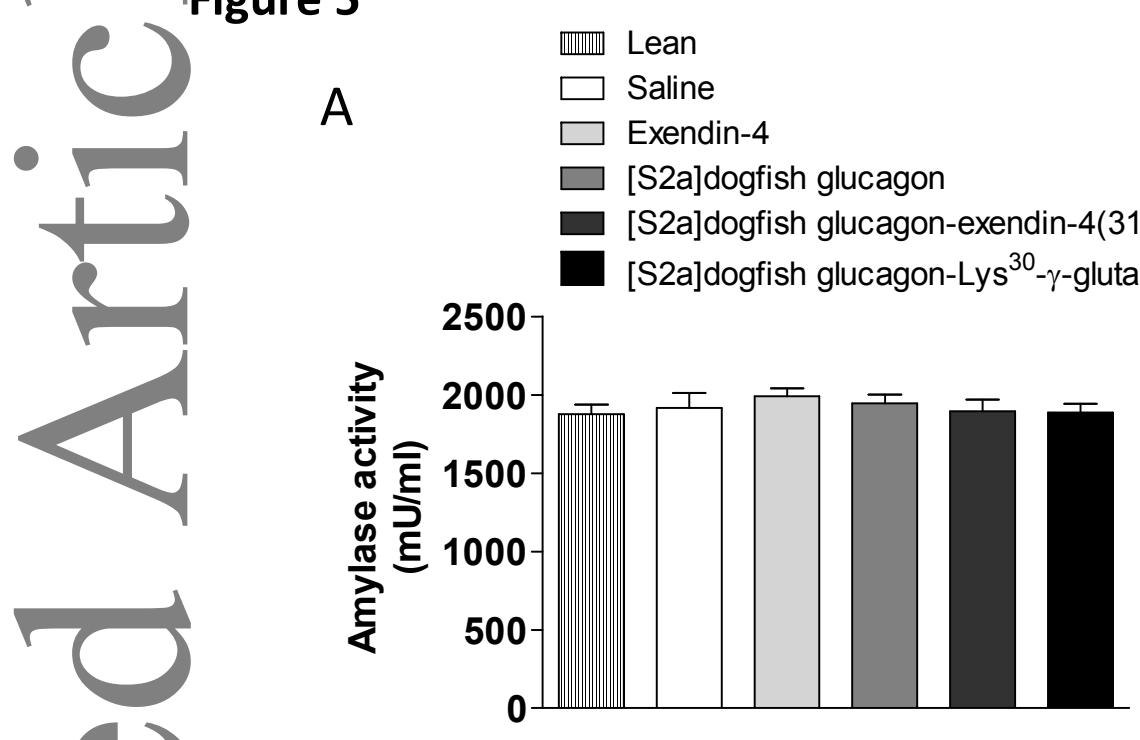

C
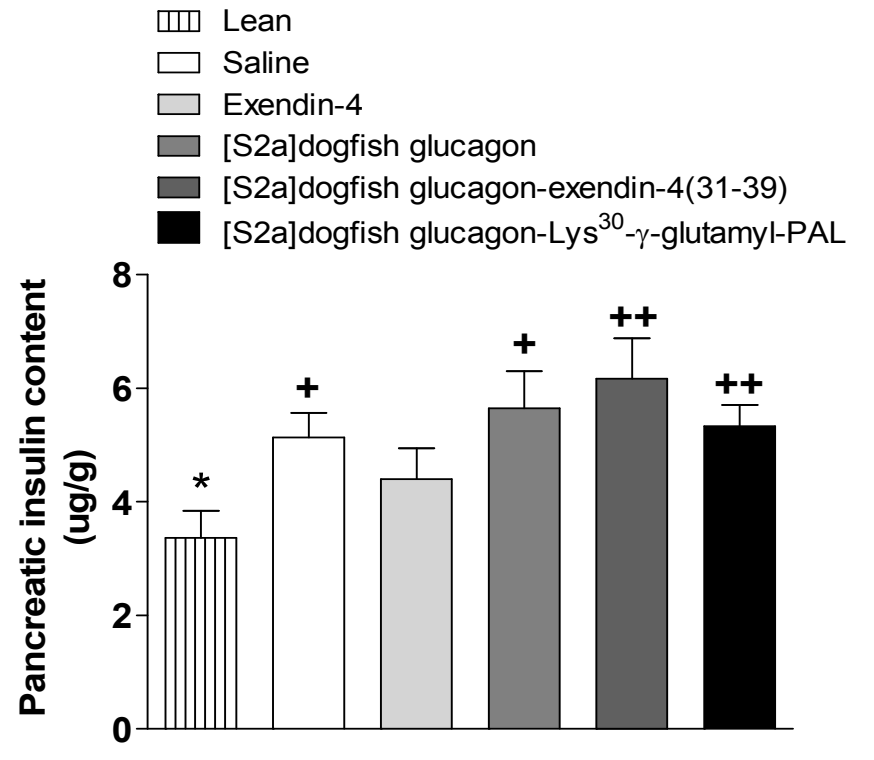

एा] Lean

$\square$ Saline

$\square$ Exendin-4

$\square$ [S2a]dogfish glucagon

[S2a]dogfish glucagon-exendin-4(31-39)

[S2a]dogfish glucagon-Lys ${ }^{30}{ }^{-}-$-glutamyI-PAL

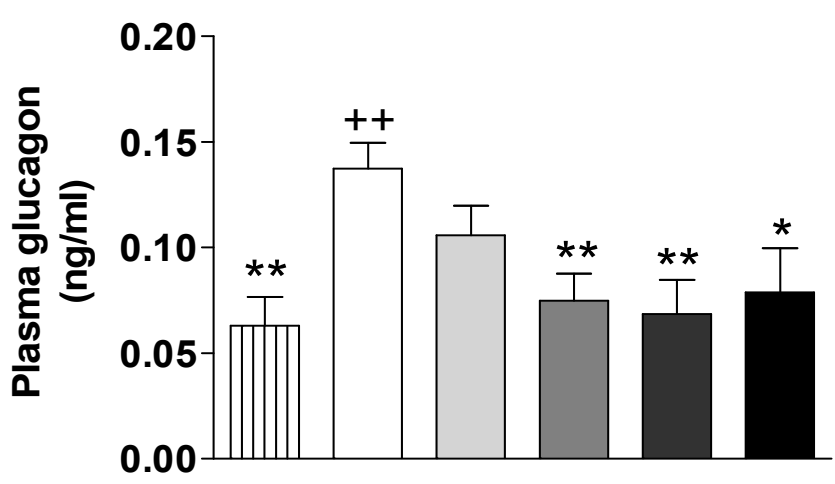

D
皿 Lean
$\square$ Saline
$\square$ Exendin-4
$\square$ [S2a]dogfish glucagon
- [S2a]dogfish glucagon-exendin-4(31-39)
[ [S2a]dogfish glucagon-Lys ${ }^{30}-\gamma$-glutamyl-PAL

4000

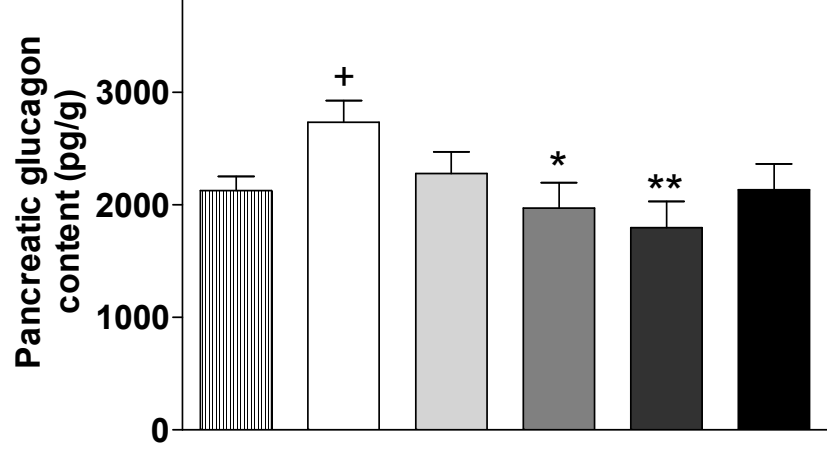

This article is protected by copyright. All rights reserved. 
(1) Figure 6A

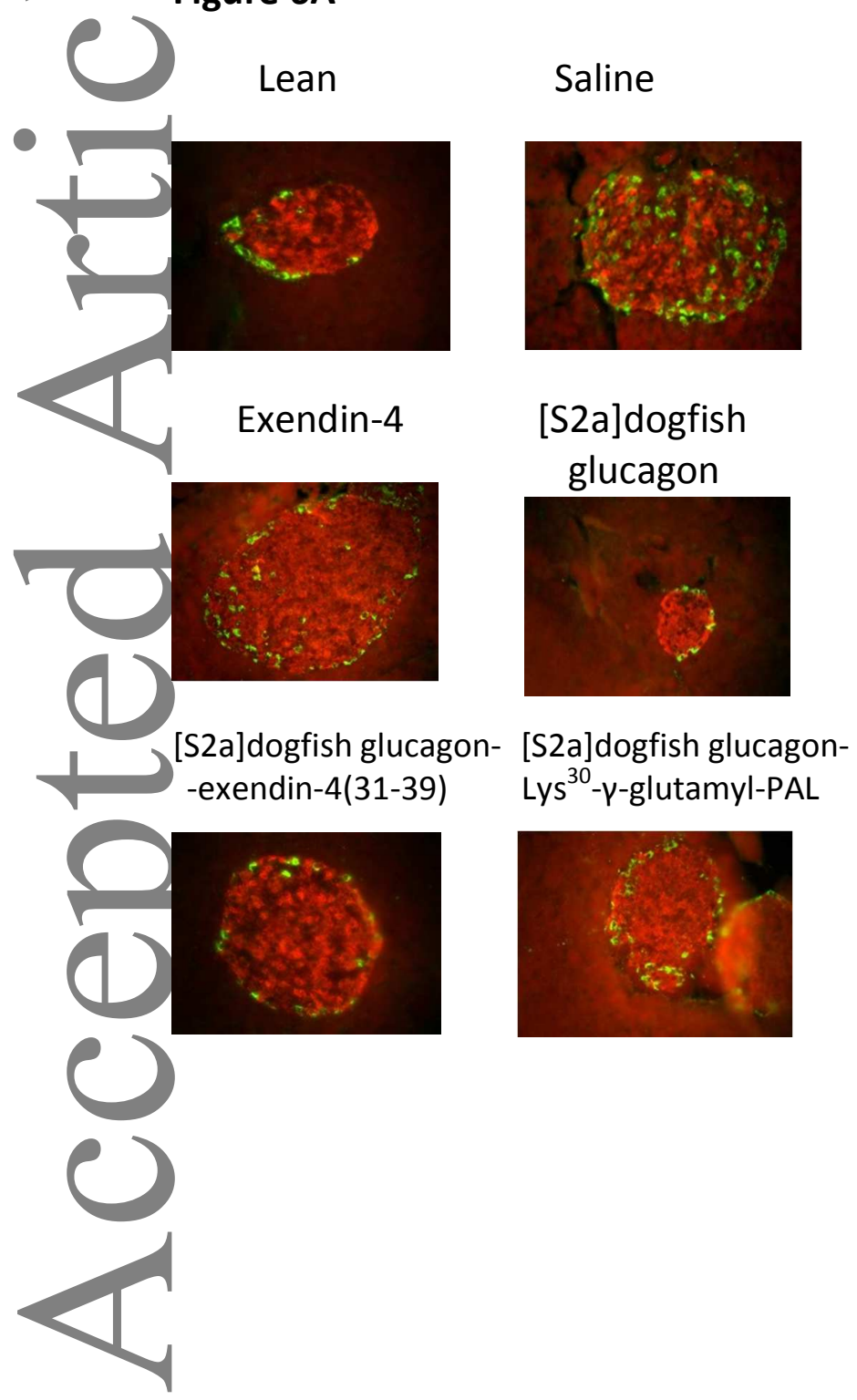

This article is protected by copyright. All rights reserved. 


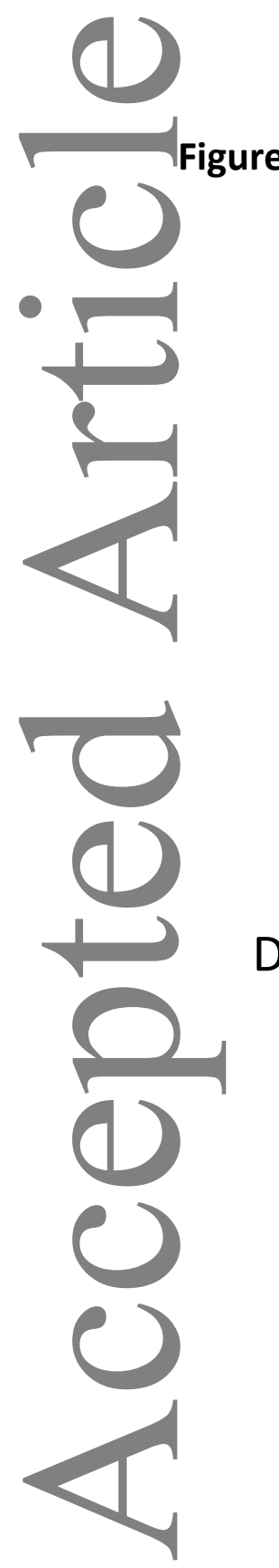

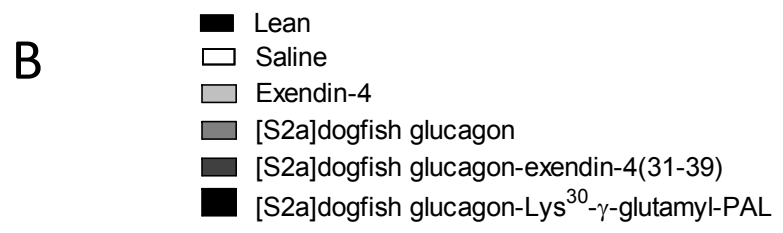

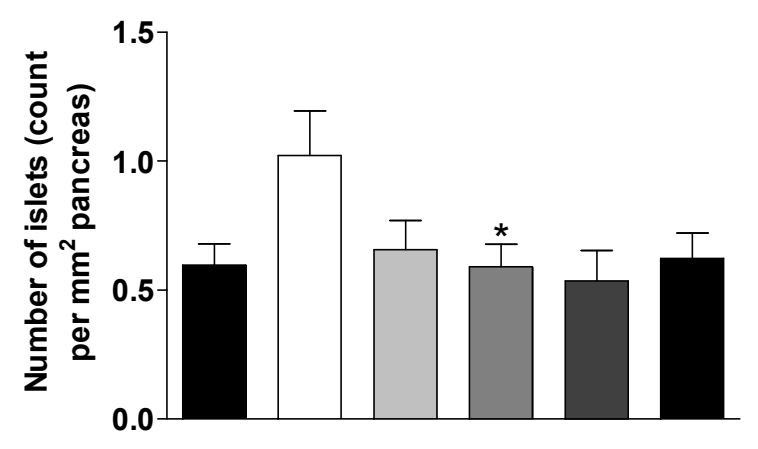

D
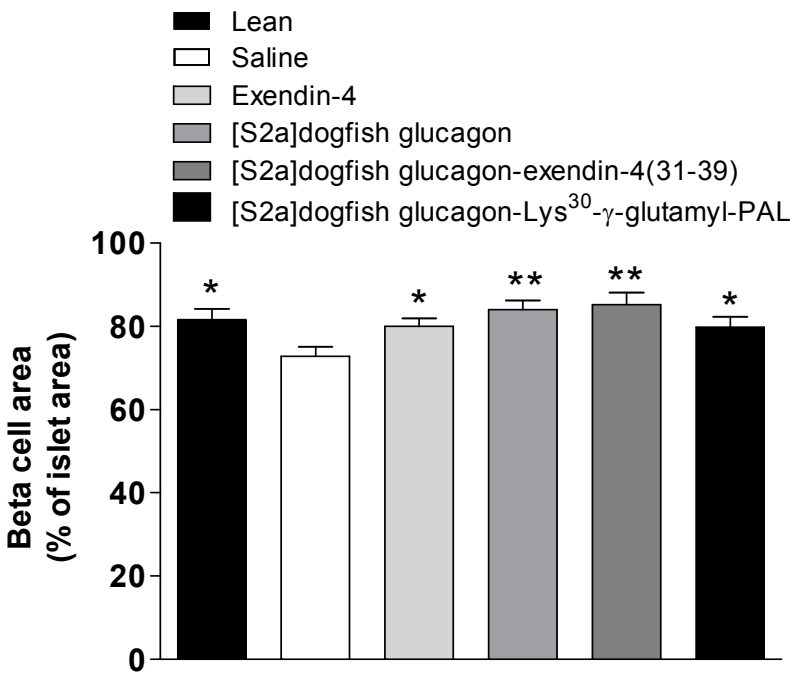

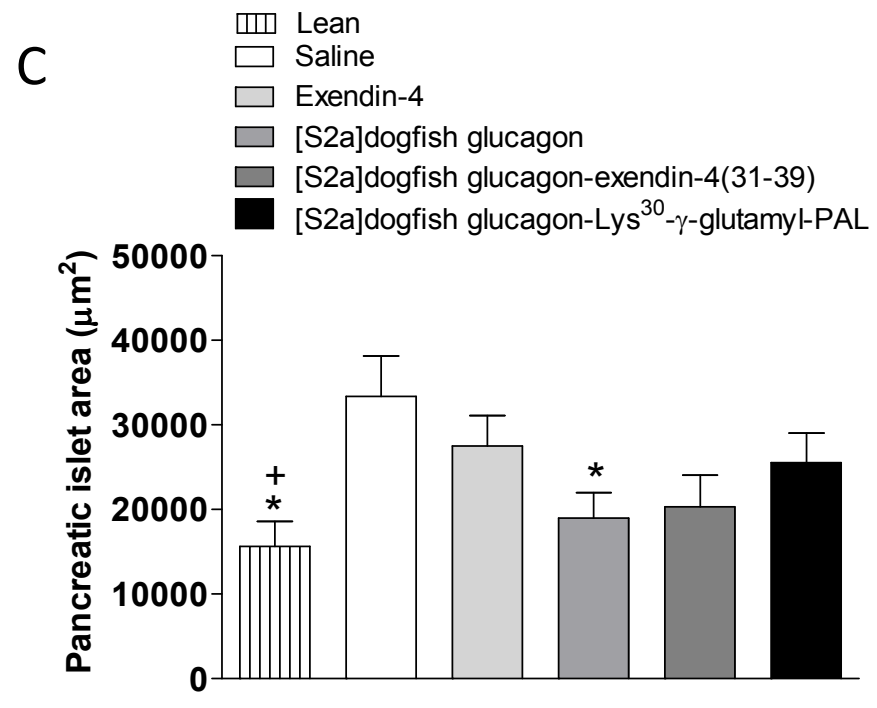
E
س Lean
$\square$ Saline
$\square$ [S2a]dogfish glucagon
[S2a]dogfish glucagon-exendin-4(31-39)
[S2a]dogfish glucagon-Lys ${ }^{30}-\gamma$-glutamyI-PAL

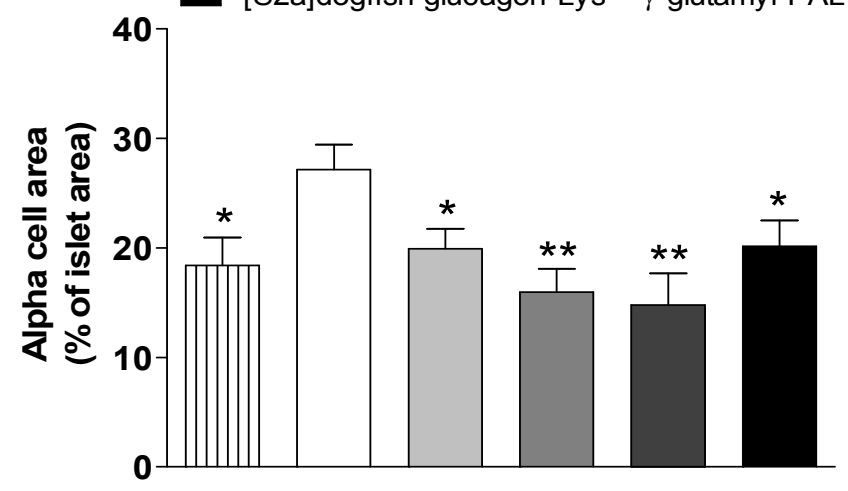

This article is protected by copyright. All rights reserved. 
TABLE 1 Comparison of primary structures dogfish glucagon, dogfish glucagon analogues and related peptides together with their theoretical/observed molecular masses.

\begin{tabular}{|c|c|c|c|}
\hline & Name & Amino acid sequence & $\begin{array}{c}\text { Theoretical } \\
\text { molecular mass } \\
\text { (Observed molecular } \\
\text { mass) }\end{array}$ \\
\hline & $\begin{array}{l}\text { Dogfish glucagon } \\
\text { (1-29) }\end{array}$ & $\begin{array}{l}\text { HSEGTFTSDYSKYMDNRRAKDFVQWLM } \\
\text { NT }\end{array}$ & $\begin{array}{c}3528.91 \\
(3528.14)\end{array}$ \\
\hline • & [Sa2]dogfish glucagon & $-a \ldots \ldots \ldots \ldots \ldots \ldots \ldots \ldots$ & $\begin{array}{c}3512.91 \\
(3514.00)\end{array}$ \\
\hline & $\begin{array}{l}\text { [S2a] dogfish glucagon- } \\
\text { exendin-4(31-39) }\end{array}$ & $\begin{array}{l}\text { a } \ldots \ldots \\
- \text {-PSSGAPPPS amide }\end{array}$ & $\begin{array}{c}4289.77 \\
(4290.31) \\
\end{array}$ \\
\hline & $\begin{array}{l}\text { [S2a] dogfish glucagon-Lys }{ }^{30}-{ }^{-} \\
\text {glutamyl-PAL }\end{array}$ & $\begin{array}{l}\text { a }-\ldots \ldots \ldots \\
- \text { - K-Y-GlutamyI-PAL }\end{array}$ & $\begin{array}{c}4008.65 \\
(4009.08)\end{array}$ \\
\hline & Human glucagon & $\cdots Q \cdots-\ldots L-S \cdots Q \cdots-\cdots$ & $\begin{array}{l}3482.80 \\
(3481.49)\end{array}$ \\
\hline & Exendin-4 & $\begin{array}{l}- \text { G - - - - - L - Q Q - E EEAVRL - , E - } \\
- \text {-PSSGAPPPSamide }\end{array}$ & $\begin{array}{c}4186.57 \\
(4186.32)\end{array}$ \\
\hline & GLP-1(7-36) amide & $\begin{array}{l}-A-\cdots--V-S-L E G Q A--E-, A--V \\
\text { KGRamide }\end{array}$ & $\begin{array}{l}3297.70 \\
(3296.03)\end{array}$ \\
\hline & GIP(1-30) & $\begin{array}{l}Y A \cdots \cdots, \cdots-\# A-K, H Q Q-\cdots N-D \\
A Q K\end{array}$ & $\begin{array}{c}3551.1 \\
(3550.9) \\
\end{array}$ \\
\hline
\end{tabular}

This article is protected by copyright. All rights reserved. 